\title{
Public-Private Partnerships: Does Russian Practice Follow International Experience?
}

\author{
Elizaveta Markovskaya \\ Candidate of Economic Sciences, Associate Professor \\ ORCID \\ E-mail: markovskaya@yandex.ru
}

Department of Finance, National Research University Higher School of Economics, St. Petersburg, Russia

\author{
Victoria Holodkova \\ Candidate of Economic Sciences, Associate Professor \\ ORCID \\ E-mail: holodkova_victoria@hotmail.com \\ Department of Economic Cybernetics, St. Petersburg State University, St. Petersburg, Russia
}

\section{Dmitry Radushinsky}

Candidate of Economic Sciences, Business Consultant

ORCID

E-mail: D.Radoushinsky@gmail.com

Intellect Challenge LLC, St. Petersburg, Russia

Journal of Corporate Finance Research, Vol. 13, No. 2, pp. 104-113 (2019)

DOI: https://doi.org/10.17323/j.jcfr.2073-0438.13.2.2019.104-113

Received 16 January 2019 | Peer-reviewed 5 March 2019 | Accepted 3 June 2019 


\section{Public-Private Partnerships: Does Russian Practice Follow International Experience?}

\section{Abstract}

Business partnerships between state agencies and private sector entities represent one of the most common forms of interaction between government and the business sector. Moreover, these public-private partnership (PPP) projects can be a major and effective catalyst for significant social and commercial development in the public sphere.

This article is devoted to an analysis of recent changes in the legislative base concerning PPP in the Russian Federation. We intend to identify pragmatic approaches toward assessing the economic effects of PPP involvement for potential stakeholders, as well as constructing models of financial frameworks for mapping the PPP project implementation. This article presents the result of testing the financial model that we propose. The ultimate intention is that this model can be used in the preparation of concession agreements and negotiation in the preparation of PPP projects.

To achieve this, we analyze the legal framework and development trends of public-private partnership projects, both theoretically and practically. We consider and evaluate PPP from the point of view of 3 aspects: organizational, methodological and managerial. To achieve this, we must identify the interests of the various stakeholders who are directly or indirectly interested in the practical results of the project in both a material and a sociopolitical sense.

For each of the stakeholders, we identify areas for them to evaluate in the process of analyzing potential PPP projects. This includes the potential quantitative and qualitative results of a project that can be identified and, as a rule, measured, which allows for a standard approach to political and commercial evaluation. As a result, we present an algorithm for building a financial model which accounts for material and seemingly immaterial variables

It is suggested that this approach to building a financial model and evaluating the effects of PPP projects provides a uniquely useful perspective on the field. We utilize the most modern methods for assessing risks, benefits and effects for various stakeholders of projects implemented in the form of PPP, and as a result this paper provides ample opportunity for further development of research. The presentation of the evaluation algorithm for PPP stakeholders takes into account the complex structure of the partnership participants and will be useful for academic, commercial, and administrative parties.

Keywords: public-private partnerships (PPP), effects and benefits for PPP stakeholders, PPP financial model, evaluation of PPP project risks and effects, forecast of PPP project development, concession

JEL classification: H54, G31, G32, G38 


\section{Introduction}

Public-Private Partnership (PPP) has been studied in detail and multilaterally both in Russia and in international contexts. For example, in a general study of the PPP phenomenon, ed. E.R.Yescombe [1] examined, among other things, the specifics of the application of PPP standards in different countries, the various shortcomings of PPPs, the decision-making processes for investing and holding state competitions in PPPs, and the practical issues of organizing financing for private companies entering into PPP agreements. An empirical analysis of the involvement of small and medium-sized businesses in PPPs and amendments to the concluded contracts was carried out by the authors of the American Planning Association, the World Bank and the EBRD $[2,3,4]$.

In other works [see 5, 6, 7, 8, 9, 10] different aspects of PPP such as prices for services in PPP projects in traditional sectors, the impact of public sector reforms on PPP, budget constraints on PPPs, risk transfer and stakeholder relationships, the influence of trust and established relationships, and regulatory regulation of PPP contracts are covered. Regional-specific experiences have also been analyzed, e.g assessing the effectiveness of PPPs in the construction of toll roads in the United States, implementing an integrated urban mega-project in the city of New Songdo in South Korea, and institutional and strategic barriers to PPP in the Netherlands [see 11, 12, 13]. In a recent paper [14] Professor J. Macomber of Harvard University discusses the possibilities of using PPPs in the four types of urban agglomerations which he outines.

We suggest a practical approach to the construction of a financial model for assessing the effectiveness of PPP projects by planning for the respective dependencies. This article describes the principles of building such a financial model, as well as the author's approach to assessing the integrated effect, taking into account the complex structure of the participants in the partnership and assessing economic effects for stakeholders.

The article analyzes the legal foundations and trends in the development of this form of interaction. Modern methods for assessing risks [8], benefits and effects for different stakeholders of projects implemented in the form of PPPs are considered. We propose to consider and evaluate PPP projects in terms of 3 aspects: organizational, methodological and managerial (stakeholder). The organizational encompasses an evaluation of the benefits of the project at different levels of functioning of the participating economic entities. The methodological approach considers that there are many methods that can be adapted for use in the process of assessing the effectiveness of PPP projects. From the point of view of project management in public-private partnership projects, there are several stakeholders: the state, business, society, etc. By 'stakeholders' we mean all individuals and / or legal entities that are directly or indirectly interested in the results of the project.
Through this method, for each of the stakeholders, we can identify the effects that are relevant to their interests in the process of PPP. By 'effects' we mean quantitative and qualitative project results that can be identified and, as a rule, measured [11].

\section{Trends in the Development of Public-Private Partnership in Russia}

On January 1, 2016 Federal Law No. 224-FZ of July 13, 2015, “On Public-Private Partnership, Municipal-Private Partnership in the Russian Federation and Amendments to Certain Legislative Acts of the Russian Federation" (hereinafter - the PPP Law ) came into force in Russia.

Prior to that, most of Russia's PPP projects were implemented under the Law on Concessions, adopted in 2005, or on the basis of regional legislation on PPPs (according to data for 2015, 71 laws on the subject of the Russian Federation in the sphere of PPP are in force in Russia).

The current state of Russian legislation on PPP is developing around three main areas: the PPP law and the expected amendments to it, concession legislation, and regional legislation [15].

At the end of the 1st quarter of 2017 "Association PPP Development Center» published the results of their research 'Public-Private Partnership in Russia 2016-2017: Current Status and Trends, Regions' Rating"'. In this document, experts identified the main trends in PPP development in Russia [16].

As of the beginning of 2017, the Russian Federation decided on the implementation of 2,446 infrastructure projects that involve private investment on the principles of PPP. At the same time, more than 480 projects are in the hands of governmental authorities and about 1,000 (according to expert estimates) are structured by a private partner for launch using the "private initiative" mechanism. Of the PPP projects that were favourably decided upon passed the decision-making stage on the implementation, 17 were at the federal level, 238 at the regional level, and 2191 were at the municipal level. A similar study (published in the 1st quarter of 2016) reported on 1300 PPP projects, for which a decision was made to implement 15 projects at the federal level, 191 projects at the regional level, and more than 1100 projects at the municipal level. Thus, the largest growth for 2016 (almost 100\%) is noted for municipal level projects, while at the regional and federal level the growth in the number of projects implemented is more moderate. With regard to municipal PPP projects, it is noted that for 2017 so far, their implementation has been delivered to a maximum of 15-20 regions of the Russian Federation, where concession mechanisms are actively used. Thus, with the expansion of the geography of implementation in the coming years, the significant growth in the number of municipal-level PPP projects is likely to continue. 
The main form of implementation of projects in the form of public-private partnerships continues to be related to the area of concession. 2,200 infrastructure projects (mainly in the municipal sector at the municipal level) are already being implemented and will be implemented in the form of a concession agreement. The term "private partner" has been used more actively since 2016, after the adoption of the law on PPP, mainly in PPP / PPP agreements in the social sphere (e.g. health, and education). To date, there are 70 such projects, all concluded within the framework of regional legislation.

The study notes that a number of projects are being implemented today in other organizational and legal forms closely related to PPP, such as: a long-term investment agreement and a life-cycle contract concluded within the framework of the 223-FZ, a life cycle contract within the framework of $44 \mathrm{FL}$, and a long-term lease of public property, which implies certain investment obligations of the lessee (the RF Civil Code and 135-FZ).

Most PPP projects are implemented in the following areas: communal and energy infrastructure ( $84 \%$ in terms of the number of projects and $27 \%$ in terms of investments), social infrastructure (11\% in terms of number of projects and $13.5 \%$ in terms of investments), transport infrastructure 3\% for the number of projects and $56 \%$ for the volume of investments). Projects in the information, communication and other spheres of PPP are $2 \%$ in terms of the number of projects and 3.5\% in terms of investments. In such areas as defense, maintenance of law and order, and the fundamental science, the legislative forms of PPP and PPP-related activity is not utilised.

\section{Some aspects of project evaluation implemented in the form of public- private partnerships}

The requirement to assess the effectiveness of projects implemented in the form of public-private partnership, starting from the moment the PPP Law comes into force, is an essential part of the organizational scheme for reviewing and analyzing the project by authorized representatives of government bodies [9].

We will hereby examine the individual aspects of the evaluation procedure, which should be implemented in the delivery of public-private partnership projects, and the legal framework which is relevant to them.

Organizational aspect. Organizationally, the evaluation process depends on the level at which decisions are taken on the project. For example, the materials of the Public-Private Partnership Development Center contain an organizational chart of the decision of the Investment Fund of the Russian Federation on PPP projects, which is set forth in Government Resolution No. 134 of March 1, 2008, "On Approving the Rules for the Formation and Use of Budgetary Appropriations of the Investment Fund of the Russian Federation" (with amendments and additions).
Organizational aspects of the decision-making process on investing in PPP projects are fixed in the following legislative acts: Resolution of the Government of the Russian Federation No. 590 of 12.08.2008 "On the procedure for inspecting investment projects for the effectiveness of using federal budget funds aimed at capital investments"; from 13.09.2010 № 716 "On approval of the rules for the formation and implementation of the federal targeted investment program"; the Decree of the Government of the Russian Federation of 03.08.2011 № 648 “On the selection and coordination of the implementation of priority investment projects of the federal districts and amendments to some acts of the Government of the Russian Federation", Resolution of the Government of the Russian Federation No. 382 of April 30, 2013 "On Conducting a Public Technological and Price Audit of Major Investment Projects with State Participation and on Amending Certain Acts of the Government of the Russian Federation"; and RF Government Decree of 05.11. 2013 No. 991 "On the procedure for assessing the appropriateness of financing investment projects at the expense of the National Welfare Fund and (or) retirement savings held in thestate management company, on a returnable basis".

Managerial aspect. In terms of the theory of project management in projects implemented in the format of public-private partnership, there are several stakeholders: the state, business, society. By stakeholders we mean individuals and / or legal entities that are directly or indirectly interested in the results of the project.

For each of the stakeholders, we can identify the effects that they can assess in the process of analyzing projects implemented in the format of public-private partnership. By effects we mean quantitative and qualitative project results that can be identified and, as a rule, measured [5]. Methodological aspect. Methodological bases for the evaluation of projects implemented in the PPP format are set out in several normative acts: The methodological recommendations for assessing the effectiveness of investment projects (approved by the Ministry of Economics of the Russian Federation, the Ministry of Finance of the Russian Federation and Gosstroy of the Russian Federation of June 21, 1999, No. V 477), the Order of the Ministry of Regional Development of the Russian Federation of October 30, 2009, No. 493 "On Approving the Methodology for Calculating Indicators and Applying Criteria for the Effectiveness of Regional Investment Projects ..." [21]

\section{Russian Practice of Financial Modeling, Risk Analysis and Effects Assessment}

\section{Estimation of the integral economic effect in case of participation of foreign or international organizations in public- private partnership projects}


To determine the integral economic effect of involving a foreign partner in joint activities to create an innovative product within a PPP, the following basic formula can be used:

$$
\text { Eief }=\mathrm{FRf} \times \mathrm{k} 1 \times \mathrm{k} 2 \times \mathrm{k} 3-\mathrm{FRd} \text {, }
$$

where FRf (NPVf) is the expected financial result from the implementation of the project to create an innovative product in the PPP with the involvement of this foreign (international) company;

' $\mathrm{k} 1$ ' is a coefficient defining the scale of the project in the suggested range $[0,8: 1,2]: 0,8$ is a municipal project, the total cost of the project is up to 100 million rubles; 1 is the regional project, the cost of which is between 100 to 500 million rubles; 1.1 is a regional or interregional project, costing between 500 million and 5 billion rubles; 1,2 is a federal project, the cost of which is more than 5 billion rubles.

' $\mathrm{k} 2$ ' is a coefficient determining the level of business reputation (fame) of this foreign (international) company involved in the implementation of the project to create an innovative product within the PPP framework in the range [1:1.5] : 1, which means the company is known in its country; 1,5 indicates that the company is the world leader, cooperation with which has the highest reputational effect;

' $\mathrm{k} 3$ ' is the ratio of the share of private capital in the project for the creation of an innovative product within the framework of PPP with the involvement of this foreign (international) company in comparison with the involvement of domestic partners or other foreign (international) companies that participate in the tender, the coefficient is determined by private respective shares;

FRd (NPVd) is the expected financial result from the implementation of a project to create an innovative product within the framework of PPP with the involvement of a domestic or foreign company that is accepted as the base option.

Moreover, formula (1) can take into account other factors, the influence (weight) of which can be determined by the method of expert estimates $[18,19]$.

\section{Approaches to building a financial model and assessing the effects of a project implemented in the form of PPPs: Russian practice}

Implementation of the project in the form of public-private partnerships should provide mutual benefits for both sides involved in the transaction, for both the public and the share of the private partner.

In general, the base principle of formation of the remuneration reflects the following understanding at a basic level - for the successful implementation of the project, costs must be offset by income from private business projects, as well as generating some profit. This principle is particularly significant for the private partner, as the public partner in PPP projects primarily performs its social function, which provides and accounts for taxpayer funds. Therefore, the public partner does not need to extract any financial benefit from the project.

Note that part of the PPP projects, at the same time is subject to the necessary and additional state regulation of tariffs. This state regulation (see Law of the Russian Federation of the PPP No. 7) affects the preparation and formation calculations in the financial model. If, (in accordance with the agreement on public-private partnership) this provides for the production of goods, works and services carried out at regulated prices/tariffs and (or) based on established allowances to the prices/tariffs, procedures and conditions for establishing and changing prices/tariffs on manufactured goods, performed work, rendered services, allowances on prices (tariffs), long-term parameters of regulation of the private partner's activities (see Law of the Russian Federation of the PPP No. 7), subject to approval in accordance with standard field of price control legislation (tariffs) in the Russian Federation.

Thus, the final version of the financial model for this project of public-private partnership can be formed only after the prices / tariffs on manufactured goods / services will be agreed with the relevant regulatory authorities.

In addition, the agreement on public-private partnership may include a charge made by the private partner during the operation and (or) maintenance of the facility agreement (see Law of the Russian Federation of the PPP, Ch. 9).

The introduction of such a payment may be provided both during the entire life of the service and / or maintenance of the object of the agreement, and during certain periods of its operation and / or maintenance. The amount of such payment, as well as its form, procedure and timing of its introduction are established by the PPP agreement.

In the construction of the project's financial model it is necessary to observe a series of actions that will form a model more accurately and correctly.

The following scheme for constructing a financial model is proposed:

1) Formation of the overall project under the PPP model (including various production and basic financial indicators).

2) Preparation of the forecasted statements (including balance sheet, profit and loss statement, cash flow statement).

3) Calculation of the pure discounted cash flow. In building the financial model for this scheme, it is necessary to consider that the amount of state participation in the transaction is determined by the size of the rate of profit and the amount of depreciation in the absence of borrowed funds.

In the presence of debt financing to private investors the rate of profit is also offset by interest paid for the use of debt financing. Thus, in order to determine the amount required to be paid, a financial model of the PPP project must be prepared. Formation of a financial model for the 
implementation of the public-private partnership project takes place taking into account the use of own and borrowed funds. As part of the formation of the financial model, the amount to be paid by the private partner into the project to cover its expenses is calculated. This amount is calculated for each year of the provision of services / sales of products, under the following conditions.

The expected amount to be received by a private partner for each calendar year for the provision of services / sales of products is calculated by the following formula:

$\mathrm{P}_{\mathrm{t}}=\mathrm{P}\left(\mathrm{I}_{\mathrm{t}}\right)+\mathrm{P}\left(\mathrm{FC}_{\mathrm{t}}\right)+\mathrm{P}\left(\mathrm{VC}_{\mathrm{t}}\right)$,

where:

$\mathrm{P}_{\mathrm{t}}$ - the expected value in year $\mathrm{t}$;

$\mathrm{P}\left(\mathrm{I}_{\mathrm{t}}\right)$ - part of the expected investment in year $\mathrm{t}$;

$\mathrm{P}\left(\mathrm{FC}_{\mathrm{t}}\right)$ - expected permanentcosts in year $\mathrm{t}$;

$\mathrm{P}\left(\mathrm{VC}_{\mathrm{t}}\right)$ - expected variable costs in year $\mathrm{t}$.

The expected value of the constant operating part in formula (1) for each t-year of the provision of services / sales of products is calculated by the following formula:

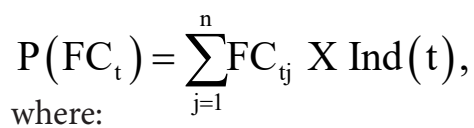

$\mathrm{FC}_{\mathrm{tj}}$ - compensation of $\mathrm{j}$-type costs for t-year;

Ind $(t)$ - the forecasted index in $t$ year.

The expected value of the operating variable part in formula (1) for each $t$ service year is calculated using the following formula:

$\mathrm{P}\left(\mathrm{VC}_{\mathrm{t}}\right)=\sum_{\mathrm{i}=1}^{\mathrm{n}} \mathrm{V}_{\mathrm{t}}(\mathrm{i}) \mathrm{X} \sum_{\mathrm{j}=1}^{\mathrm{m}} \mathrm{VC}_{\mathrm{tj}} \mathrm{X} \operatorname{Ind}_{\mathrm{j}}(\mathrm{t})$,

$\mathrm{V}_{\mathrm{t}}(\mathrm{i})$ - expected volume of the i-th type of services / goods in year t;

$\mathrm{VC}_{\mathrm{tj}}$ - compensation costs in the form of $\mathrm{j}$-th for year $\mathrm{t}$;

Ind $_{j}(t)$ - forecast the index $\mathrm{j}$-th species in year $\mathrm{t}$.

When building a financial model of public-private partnerships, one must take into account that the value of the sum necessary for the private partners for the project should be not less than the sum itself (formula 1).

Thus, if we calculate the financial model of a project implemented through a public-private partnership scheme (a simplified example of such a calculation is given below, see Table 2.), the amounts of subsidies received should be calculated taking into account the constraints obtained by formulas (2)-(4).

Table 1. Simplified financial model for calculating the subsidy for falling costs in the PPP model

\begin{tabular}{|c|c|c|c|c|c|}
\hline Indicator name & Units & 2017 & 2018 & 2019 & 2020 \\
\hline Income from goods / services & rub. & 54872 & 58620 & 61025 & 64230 \\
\hline Income from non-core activities & rub. & 4510 & 4826 & 5163 & 5525 \\
\hline Total revenues & rub. & 59382 & 63446 & 66188 & 69755 \\
\hline Cost of sales of goods / services & rub. & 32923 & 35172 & 36615 & 38538 \\
\hline Production costs & rub. & 5487 & 5862 & 6103 & 6423 \\
\hline Depreciation & rub. & 20500 & 20500 & 20500 & 20500 \\
\hline Property tax & rub. & 560 & 560 & 560 & 560 \\
\hline $\begin{array}{l}\text { Expenditures for social develop- } \\
\text { ment and other purposes }\end{array}$ & rub. & 1540 & 1540 & 1540 & 1540 \\
\hline Project management costs & rub. & 420 & 420 & 420 & 420 \\
\hline Interest on loans & rub. & 890 & 890 & 890 & 890 \\
\hline Total costs & rub. & 62320 & 64944 & 66628 & 68871 \\
\hline Drop-out costs & rub. & 2938 & 1498 & 439 & -884 \\
\hline Subsidies from the budget & rub. & 2938 & 1498 & 439 & -884 \\
\hline
\end{tabular}


In addition, in the implementation stage of the project, the formula may also take into account the income of the investor from the project. That is part of the amount $\mathrm{P}_{\mathrm{t}}$ at the relevant stage of operation of the project that can be covered through income from the project itself.

Most of the projects implemented in the format of public-private partnerships imply a gradual coverage of the investor's expenses for the project implementation at the expense of revenues received from its implementation.

However, it is also necessary to take into account that the investor pays attention not only to the gross income, but also to the distribution of funds over time.

In conclusion, it should be noted that any involvedment in a PPP necessitates an interest in the project. As a private investor, this will take the form of financial benefits, and for the state party, in the form of the implementation necessary for the requirements of the state, e.g., to ensure public infrastructure, social facilities and other such tasks, as are traditionally resolved at the state level [17].

\section{Approaches to risk assessment of PPPs: Russian practice}

Here, we will consider examples of practical implementation of methodological recommendations for the evaluation of regional projects.

Below are examples of regional approaches to the implementation of guidelines for project evaluation. These approaches are related to the implementation of the rating-rating system of project evaluation.

\section{Example 1.}

The rating system for the evaluation of projects for the development of entrepreneurship in the Cherek Municipal District of the Kabardino-Balkarian Republic

Table 2. Criteria for assessing the local administration of the Chereksky Municipal District when giving grants to entrepreneurs

\begin{tabular}{|c|c|c|c|}
\hline Criteria & Indicator & Grade & Weight of criteria \\
\hline 1 & 2 & 3 & \\
\hline \multirow{2}{*}{ Land for project implementation } & ownership & 100 & \multirow{2}{*}{0,2} \\
\hline & Rent & 80 & \\
\hline \multirow{2}{*}{ Creation of additional work places } & More than 3 & 100 & \multirow{2}{*}{0,3} \\
\hline & 3 & 80 & \\
\hline \multirow{2}{*}{ Weight of equity in the total investment } & $15 \%$ & 80 & \multirow{2}{*}{0,2} \\
\hline & More than 15\% & 100 & \\
\hline \multirow{2}{*}{$\begin{array}{l}\text { Own fixed assets (infrastructure, equipment, } \\
\text { tools etc) }\end{array}$} & yes & 100 & \multirow{2}{*}{0,1} \\
\hline & no & 0 & \\
\hline \multirow{6}{*}{ Business lines } & agriculture & 100 & \multirow{6}{*}{0,1} \\
\hline & tourism & 80 & \\
\hline & manufacturing & 70 & \\
\hline & services & 60 & \\
\hline & arts & 50 & \\
\hline & trade & 40 & \\
\hline \multirow{2}{*}{ Correspondence with project documentation } & corresponds & 100 & \multirow{2}{*}{0,1} \\
\hline & Does not correspond & 0 & \\
\hline
\end{tabular}

Source: Developed by Markovskaya E.I. together with Isupov AR, representative of the administration of the Chereksky Municipal District of the Kabardino-Balkarian Republic within the framework of the Presidential Program, 2015. 
Table 3. The main directions of the study of the external and internal environment of the project / project initiator, the relevant indicators and their specific gravities

\begin{tabular}{|c|c|c|c|c|c|}
\hline \multirow[t]{2}{*}{ Project characteristics } & \multicolumn{2}{|c|}{ Weight } & \multirow[t]{2}{*}{ indicator } & \multicolumn{2}{|c|}{ Weight } \\
\hline & $\begin{array}{l}\text { Project } \\
\text { finance }\end{array}$ & $\begin{array}{l}\text { Investment } \\
\text { loans }\end{array}$ & & $\begin{array}{l}\text { Project } \\
\text { finance }\end{array}$ & $\begin{array}{l}\text { Investment } \\
\text { loans }\end{array}$ \\
\hline \multirow{5}{*}{$\begin{array}{l}\text { Project Initiator } \\
\text { Owners }\end{array}$} & \multirow{5}{*}{0,1} & \multirow{5}{*}{0,4} & Influence of owners & 0,3 & 0,3 \\
\hline & & & Stability of business & 0,2 & 0,2 \\
\hline & & & Experience in Project Realization & 0,2 & 0,2 \\
\hline & & & Financial Performance & 0,1 & 0,1 \\
\hline & & & Goodwill & 0,2 & 0,2 \\
\hline \multirow{7}{*}{ Project peculiarities } & \multirow{7}{*}{0,6} & \multirow{7}{*}{0,2} & Financial Model & 0,2 & 0,3 \\
\hline & & & Marketing and Sales & 0,2 & 0,15 \\
\hline & & & Supply & 0,2 & 0,15 \\
\hline & & & Assets creation & 0,1 & 0,1 \\
\hline & & & Exploitation Stage & 0,1 & 0,1 \\
\hline & & & Political Risks & 0,1 & 0,1 \\
\hline & & & Other & 0,1 & 0,1 \\
\hline \multirow{3}{*}{$\begin{array}{l}\text { Credit or investment deal } \\
\text { peculiarities }\end{array}$} & \multirow{3}{*}{0,3} & \multirow{3}{*}{0,4} & Loan Guarantees & 0,4 & 0,4 \\
\hline & & & Additional Finance Sources & 0,3 & 0,3 \\
\hline & & & Level of Control & 0,3 & 0,3 \\
\hline
\end{tabular}

When submitting an application, the applicant can provide any additional documents, including a letter of recommendation (letter) from public organizations, or guarantors, if he believes that they can influence the decision of the competitive commission. Additionally submitted documents are also subject to inclusion in the inventory. The commission assesses the submitted additional documents in points by a majority of votes, but not more than 20 points in total. A project that has earned scores from 70 to 100 qualifies as a recipient of the grant.

As we can see, the relationship criteria-indicators-scores given in the methodology express the stakeholder expectations associated with obtaining certain effects through participation the project.

Projects implemented in the form of public-private partnerships are implemented on the basis of the idea of sharing risks between all project participants. This principle is fundamental for project financing. Therefore, to analyze the risks of public-private partnership projects, it is possible to use methods that are designed to assess the risks of long-term financing.

As an example for these purposes, the methodology developed by Markovskaya EI can be adapted. Initially, this methodology was developed for JSC "AB Russia" in the period 2007-2008 in order to assess the bank's risks in project financing. Since project financing involves the participation of several stakeholders, including creditors and investors (the bank can also act as a co-investor of the transaction), this methodology includes risk assessment in different points of view ${ }^{1}[20,21]$.

The purpose of the methodology is to determine the level of credit risk R1 for deciding whether to participate in the transaction. The assessment of the level of credit risk R1 is carried out on the basis of an analysis of the main indicators that characterize the state of the external and internal environment of the initiator of the project.

The directions of analysis and the indicators included in their composition are presented in Table 3. The distribu-

\footnotetext{
${ }^{1}$ The entire methodology is published in the following sources: Markovskaya EI Evaluation of the risks of long-term financing of investment projects in the Russian environment: // Audit and financial analysis . No. 5. 2013; Markovskaya E.I. Organization of financing of investment projects: theory and practice. SPb.: Publishing House of Polytechnic University, 2013.
} 
tion of specific weights was made taking into account the importance of certain factors in the analysis of projects financed on the principles of project financing and investment lending. For example, the specific weight of the factor "project characteristics" in the case of project financing is 0.6 , and in the case of investment lending it is 0.2. This is due to the fact that in the case of project financing, particular attention is paid to the project in the process of long-term risk analysis because it is the cash flows generated by the project that are the source of income for investors, as well as the source of debt repayment for the bank.

Calculation of the numerical value of the risk level R1 is carried out as follows:

- the study of the initiator of the project and its external environment for each indicator is carried out;

- the values of the indicators and their corresponding grades are determined; if the indicator includes subgroups, a score is determined for each subgroup;
- the values of the indicators, which include subgroups, are calculated by multiplying the grades by subgroups by their specific weights and by summing up the weighted indicators;

- weighted values of indicators are calculated by multiplying their gross values (the sums obtained by subgroups) by their specific weights;

- an estimate of the level of risk for each direction of the study of the internal and external environment of the initiator is calculated by summing the weighted estimates of the indicators in each direction;

- a final assessment of the level of risk R1 is calculated by multiplying the risk estimates by the research directions by the corresponding specific weights and summing the weighted values.

Based on the numerical risk assessment of R1, the bank / investor's participation in project financing and the nature of the financial condition of the initiator (to determine the quality of credit resources in case of participating in financing a bank project) are determined.

Table 4. Classification of the financial condition and the possibility of participating in the project, based on an assessment of the level of risk R1

\begin{tabular}{|c|c|c|}
\hline $\begin{array}{l}\text { Financial } \\
\text { Performance }\end{array}$ & $\begin{array}{l}\text { Risk assessment R1 } \\
\text { grades }\end{array}$ & interpretation \\
\hline \multirow{2}{*}{ Good } & $65-100$ & Participation in financing is possible \\
\hline & $45-65$ & Participation in financing is possible with additional conditions \\
\hline Medium & $25-45$ & The project needs some changes \\
\hline $\mathrm{Bad}$ & $0-25$ & Participation in financing is complicated \\
\hline
\end{tabular}

\section{Conclusion}

In this composition, we have analyzed the trends in the development of the public-private partnership in Russia, and the new possibilities it offers. We have also examined the constraints of a Russian PPP Law which has been operating since 2016. While considering the aspects of project evaluation implemented in the form of PPP, we seek an approach to the construction of a financial model to assess the effectiveness of PPP projects that takes into account all the respective dependencies.

The principles of building a financial model have been described, which take into account the most modern methods for risk assessment, and the benefits and effects for different stakeholders of projects implemented in the form of PPPs. In the final part, this article describes an approach for assessing the overall integrated effect, taking into account the complex structure of the participants in the partnership and assessment of economic effects and risks for stakeholders.

We examined approaches that can be used by stakeholders in the process of assessing the risks and effects of public-private partnership projects. Taking into account the relevant risks, the method for identifying fair price of participation in the PPP project for both parties is estimated. The proposed financial model can be used to calculate the concession fee in tariff-regulated projects where the state is supposed to participate, usually with a subsequent transfer of ownership for the created entity to the state.

In furtherance of the continuous development of research in areas relevant to this article, the development of a methodology for assessing the risks and effects of public-private partnership projects (taking into account industry specificity) could be extremely useful froms practical and technical perspectives. This study may be considered a uniquely useful bridgehead in setting up the next step.

\section{References}

1. Yescombe E.R., Farquharson E. Public-private partnerships for infrastructure: Principles of policy and finance. $2^{\text {nd }}$ ed. Oxford, Cambridge, MA: Butterworth-Heinemann; 2018. 548 p. 
2. Sagalyn L.B. Public/private development: Lessons from history, research and practice. Journal of the American Planning Association. 2007;73(1):7-22. DOI: $10.1080 / 01944360708976133$

3. Chao J., Toro A.M. How to foster a more inclusive environment for SMEs in PPPs? World Bank Group. URL: https://ppp.worldbank.org/public-privatepartnership/how-foster-more-inclusive-environmentsmes-ppps (accessed on 13.09.2017).

4. Beuve J., de Brux J., Saussier S. Renegotiations, discretion and contract renewals: An empirical analysis of public-private agreements. 2014. URL: http://chaire-eppp.org/files_chaire/beuve_et_al._ wp_2014_0.pdf

5. Makovšek, D. Public-private partnerships, traditionally financed projects, and their price. Journal of Transport Economics and Policy. 2013;47(1):143-155.

6. Caperchione E., Demirag I., Grossi G. Public sector reforms and public private partnerships: Overview and research agenda. Accounting Forum. 2017;41(1):1-7. DOI: 10.1016/j.accfor.2017.01.003

7. Buso M., Marty F., Tran P.T. Public-private partnerships from budget constraints: Looking for debt hiding? International Journal of Industrial Organization. 2017;51:56-84. DOI: 10.1016/j. ijindorg.2016.12.002

8. Burke R., Demirag I. Risk transfer and stakeholder relationships in public private partnerships. Accounting Forum. 2017;41(1):28-43. DOI: 10.1016/j. accfor.2016.06.004

9. Benítez-Ávila C., Hartmann A., Dewulf G., Henseler J. Interplay of relational and contractual governance in public-private partnerships: The mediating role of relational norms, trust and partners' contribution. International Journal of Project Management. 2018;36(3):429-443. DOI: 10.1016/j. ijproman.2017.12.005

10. Ruiz Diaz G. The contractual and administrative regulation of public-private partnership. Utilities Policy. 2017;48:109-121. DOI: 10.1016/j. jup.2016.04.011

11. Kweun J.Y., Wheeler P.K., Gifford J.L. Evaluating highway public-private partnerships: Evidence from U.S. value for money studies. Transport Policy. 2018;62:12-20. DOI: 10.1016/j.tranpol.2017.03.009

12. Kim Y.-J. Contracting-out public-private partnerships in mega-scale developments: The case of New Songdo City in Korea. Cities. 2018;72(Pt. A):43-50. DOI: 10.1016/j.cities.2017.07.021
13. Klijn E.-H., Teisman G.R. Institutional and strategic barriers to public-private partnership: An analysis of Dutch cases. Public Money \& Management. 2003;23(3):137-146. DOI: DOI: 10.1111/14679302.00361

14. Macomber J.D. The 4 types of cities and how to prepare them for the future. Harvard Business Review. 2016;(Jan.) URL: https://hbr.org/2016/01/the-4types-of-cities-and-how-to-prepare-them-for-thefuture

15. Kryukova E.L., Lemieva I.V. Public-private partnership development trends. Gosudarstvennochastnoe partnerstvo = Journal of Public-Private Partnership. 2016;3(1):53-62. DOI: 10.18334/ ppp.3.1.35138 (in Russ.).

16. Markovskaya E.I., ed. GR. The interaction of business and government. Moscow: Urait Publ.; 2017. 378 p. (in Russ.).

17. Markovskaya E., Holodkova V., Radoushinsky D., Feoktistova O., Borisova A. Public-private partnerships: Approaches to assessing economic effects for stakeholders. MATEC Web of Conferences. 2018;170(1):01047. DOI: 10.1051/ matecconf/201817001047

18. Radoushinsky D.A. The impact of public-private partnerships on the development of communicative environment of innovative economy. Nauchnotekhnicheskie vedomosti Sankt-Peterburgskogo gosudarstvennogo politekhnicheskogo universiteta. Ekonomicheskie nauki $=$ St. Petersburg State Polytechnical University Journal. Economics. 2016;(5):57-71. DOI: 10.5862/JE.251.6

19. Radoushinsky D.A., Markovskaya E.I. Assessment of the integrated economic effect from the attraction of foreign partners to public-private partnerships. Den'gi $i$ kredit $=$ Russian Journal of Money and Finance. 2017;(10):33-39. (in Russ.).

20. Markovskaya E.I. Organization of financing of investment projects: Theory and practice. St. Petersburg: Polytechnic University Publ.; 2013. 183 p. (in Russ.).

21. Markovskaya E.I. Risk assessment of long-term financing of investment projects in Russian conditions. Audit $i$ finansovyi analiz = Audit and Financial Analysis. 2013;(5):222-231. (in Russ.). 